\title{
THE ROLE OF INFORMAL STRUCTURES IN ARCHITECTURAL DESIGN EDUCATION
}

Ress. Assist. Huseyin OZDEMIR

Faculty of Architecture and Design, Department of Architecture, Konya Technic University, Konya, Turkey

Assoc. Prof. Dr. Gokce KETIZMEN ONAL

Faculty of Engineering and Architecture, Department of Architecture, Eskisehir Osmangazi University, Eskisehir, Turkey

Prof. Dr. Aysen CELEN OZTURK

Faculty of Engineering and Architecture, Department of Architecture, Eskisehir Osmangazi University, Eskisehir, Turkey

\begin{abstract}
Informal education contributes to the development of the student's design skills and the performance of architecture education by addressing subjects that do not fall directly into the curriculum. This study is mainly about the development of students' design thinking skills in informal education. In order to make an assessment, a case study was conducted on the Bademlik Design Festival (BTF), which can be described as an important example in the field of informal education. By adhering to the method, surveys were applied to the instructors and students participating in the BTF. The concepts obtained according to the survey results are based on a detailed conceptual framework. Then, by interpreting this conceptual framework, students' learning outcomes are revealed. As a result, it is observed that the students in the workshops conducted at the BTF gain design thinking skills such as "interaction, free and original thinking, innovation, communication and dialogue”.
\end{abstract}

Key words: Architecture education, Architectural design education, Bademlik Design Festival, Informality, Workshops

\section{INTRODUCTION}

Education is what one does for himself (Schön, 1983). Education, in its most general sense, stands at the point where the future of the individual is shaped and the foundations of knowledge are laid. Education, therefore, is always at the center of the individual.

Recently, the context and content of architectural design tools and actions, have been constantly changing, diversifying, transforming and evolving (Öztürk, 2019). One of the transformations is on 'Lifelong Learning'(Learning by doing and living in a lifelong process). Studies such as Integrative Learning Network model (Koper \& Tattersall, 2004), the Learning Contract 
Approach in architectural design studio (Hassanpour, Che-Ani, Usman, Johar, \& Tawil, 2015), task design and the design of learning environments (Goodyear, 2000) which focus on Lifelong Learning, make informal education more and more important. Informality, which aims to go beyond the normal, the ordinary, presents a new environment, a new reality in which the accepted hierarchy, outside the existing order and rules, is destroyed (Yürekli \& Yürekli, 2004). In much of literature, education is classified as formal, informal and non-formal (Vadeboncoeur, 2006). Formal architectural education is to be structured around compulsory theoretical and studio courses where one-to-one tutorials, small group critiques, and significant quantities of individual formative feedback and guidance sessions are led (Kahvecioğlu, 2007). Informal educational environments can express emotions and thoughts free from constraints more independently, and learners experience architectural design through their personal initiatives (Ciravoğlu, 2001).

The aim of this study is to investigate the contribution of the Bademlik Design Festival to students' design thinking skills. Within the scope of the study, the Bademlik Design Festival organized in 2018 with the theme "Past-Now, Now-Future" was examined. BTF organized by the students of Design Club at Eskisehir Osmangazi University (ESOGU). BTF takes place each year with a different theme. Under the theme of the Festival, instructors develop a workshop program related to the Festival's theme through visual, aural and tactile design tools. Students from different universities in Turkey apply as candidates that they attend voluntarily and these applications are evaluated by Design Club Students. The activity offers environments that can accommodate participants from different disciplines and address different architectural issues. For this reason, the organization is valuable in terms of students learning new information, creative thinking, making free and original design, group work habit, and interdisciplinary cooperation.

The ESOGU Design Club directed by groups of architecture students from different semesters where they control the entire process of the Festival. Design Club students take an active role until they graduate. New candidates get involved each semester, where the expert ones teach the whole process to the novices. This shows that Organization is a kind of social and educational society where students actions not only as instructor, but also learner. In addition, BTF activity is seen as an important achievement for students to take responsibility, gain confidence by running a large organization and develop a sense of belonging to the University.

\section{INFORMAL STUDIES IN ARCHITECTURE EDUCATION}

Formal education corresponds to a systematic, organized education model, structured and administered according to a given set of laws and norms, presenting a rather rigid curriculum as regards objectives, content and methodology (Dib, 1988). İnformal education, which is the 
education outside the confines of curricula, includes the acquisition of knowledge and skills through experience, reading, social contact, etc. (Turgut \& Cantürk, 2015).

The components of the system of interaction between formal and informal education are shaped by approaches to learning from the literature. Some of the learning approaches from the literature are reflective learning (Schön), learning by doing (Dewey), total studio (Levy) and design model (Ledewitz). Dewey aims to actively participate in the process through a learning by doing approach, learning by doing and living, conducting collaborative work, and gaining general skills. According to Schön, the learning of knowledge takes place experientially (knowledge learned through actions) (Schön, 1985). Levy (1980) offers a proposal for the disconnection between technical and design education over the concept of total studio. Ledewitz (1985) proposes the concept-test model. The informal education system is grift with these learning approaches (Table 1). This structure demonstrates the network of interaction with other components of informal education. This whole system guides the way to new knowledge and learning.

Coombs and Ahmed (1974) draw attention to the importance of informal education by obtaining knowledge, skills and attitude from the environmental conditions in which man resides. In this context, Coombs and Ahmed (1974) emphasize the lifelong learning of a person (educated or uneducated). Informality creates an environment in which students present their ideas in a free flow, reveal their identity, and act intuitively (Ciravoğlu, 2001; Yürekli, 2003).

Informality allows the student to create an environment of free thought necessary to provoke creativity (Ciravoğlu, 2003). It also enables the development of students' creativity and cognitive activities (Önal, 2017). In some studies on informal education has been directly ascribed to the issues of increasing the professional development of students (Adigüzel, 2012), expanding the perspectives of students (Beycan, Kuyrukçu, \& Kuyrukçu, 2014; Erktin \& Soygeniş, 2014; Polatoglu \& Vural, 2012) and giving skills that cannot be acquired in formal education (İnce \& Yarkataş, 2017)

Table 1. Interaction of formal, informal and forms of learning from literature (the graph was developed by Özdemir, 2018).

The system of education in the information age should be flexible, experimental, experiencebased, giving problem-solving skills, teaching access to knowledge as well as knowledge, interdisciplinary and critical. But it has been accepted by many educators that not all of these characteristics can be achieved through the formal education system (İnce \& Yarkataş, 2017). In this direction, architecture students finding the formal design education that is given to them insufficient, instead of waiting for their desires to be satisfied by the institutions or the academic staff, choose to seek experiences on their own in a setting that every actor is special with their Received 24 Octaber 2020; Received in revised form I December 2020; Accepted 5 December 2020; 
different identities in the experience (Türkmen, 2020). This paves the way for the development of completely student-centered management, control and implementation mechanisms outside of formal education.

While Önal (2017) examined the dimensions of creativity in design education on Bademlik Design Festival, Türkmen (2020) examined the students' experience of designing and learning in outer studio. However, there is no evidence that the Festival helps students' design thinking skills. Therefore, in this study, in order to better understand the importance of informal education environments, Bademlik Design Festival (BTF) is investigated in detail and the contributions and gains of BTF to architectural design ideas and practices are discussed. This study can be an important source of data for current and future efforts to develop students' design thinking skills.

\section{FIELD OF STUDY: BADEMLIK DESIGN FESTIVAL}

Bademlik Design Festival (BTF) is organized by Design Club students of Eskisehir Osmangazi University (ESOGU) Department of Architecture since April 2013 in Bademlik Campus. The Festival is held by students with different design disciplines accompanied by professional instructors. It contains many social activities such as workshops, exhibitions, demonstrations.

Figure 1. Eskisehir Osmangazi University Department of Architecture Bademlik Campus

The aim of the festival is to gather participants from different design disciplines under the same roof, to enrich the sharing with professional workshop instructors, to gain practicality for theoretical and experimental work and to draw attention to the historical Odunpazar1 region where Bademlik campus is located. In April or May, once a year, the Festival covers a period of 3-4 days. From 2013 to the present, the Festival has hosted many workshops under different themes. It is valuable for the festival to be student-oriented, to have participants from different disciplines, and to participate in professional instructors.

Workshops were organized by Bademlik Design Festival Student Club under the themes “Think-Design-Work" in 2013, “Invasion” in 2014, “Stain” in 2015, "What Does Design Do When Layout Disintegrates” in 2016 and "5 N 1 Intervention” in 2017 (Table 2). These workshops are conducted by expert instructors in the field. Instructors carry out the operation of the workshops both theoretically and experimentally. The topics of the workshops organized within the scope of BTF are completely different from each other. In the workshops, products 
are revealed according to the subject determined by the instructors. Usually, the determined subjects are in the area of expertise of the instructors. For the efficiency of the workshops, instructors prefer workshop subjects/themes that students can produce in a short time. Each workshop works independently until the result products are produced. Products produced by students are exhibited at the end of the festival and a discussion atmosphere is created. As a result, all students have ideas about the products of the workshops conducted under BTF.

Table 2. Bademlik Design Festival themes and workshops from 2013 to 2017 (Özdemir, 2018)

\section{MATERIAL AND METHOD}

In the study, literature review of the Bademlik Design Festival, an informal education environments, was examined in detail. Önal and Turkmen focused on the Bademlik Design Festival in their work. While Önal (2017) explored the design dimensions of creativity in the festival special, Turkmen (2020) explored the students ' experience of learning and designing in the external studio. However, there is no evidence that the Festival helps students' design thinking skills. Therefore, in this study, in order to better understand the importance of informal education environments, Bademlik Design Festival (BTF) is investigated in detail and the contributions and gains of BTF to architectural design ideas and practices are discussed.

At the end of the Bademlik Design Festival, students and instructors were surveyed. Surveys consist of open-ended and closed-type questions. Open-ended questions tried to detect the comment that participants had about the question, while closed-type questions tried to obtain direct information. The concepts obtained according to the survey results are based on a detailed conceptual framework. Then, an assessment was made to determine the contributions and gains of students participating in BTF through this conceptual framework.

\section{Table 3. Method of Research}

\section{DESIGN TASK OF FESTIVAL}

Bademlik Design Festival (BTF) activity is conducted by ESOGU Architecture Department Design Club students. BTF is a student-centered activity. Expert instructors from different departments are invited by the Design Club. Instructors determine the topics of the workshops according to their area of expertise. BTF Design Club accepts students from all levels on a 'volunteer' basis under the specified subjects. Students are grouped by design club according to the workshops they want to work in. Then workshops are put into practice. 
The study is part of the Bademlik Design Festival held on 27-28-29 April 2018, which brings together students from different universities, fields and semesters. The main theme of the Festival is "Past-Now, Now-Future". It consists of nine workshops covering different topics including Phrygian Legends, Time of Water, Performative Bodies, Pinhole, Archive-Assembly, Hither and Beyond, Fast and Accurate Prototyping, Onbetaalbaar, Remember-Forget-Save-Reestablish (Table 4). By adhering to these themes, students try to solve their own design problem. Students in the workshops produce solutions to the design problem within 3 days.

Table 4. Bademlik Design Festival Workshops held in 2018

On the first day of the Festival, the instructors in the workshops explain the scope and purpose of the study to the students. And then, instructors perform a power point presentation by showing examples. As part of the workshop theme, instructor state the design problem to students. On the second day of the festival, students in the workshops determine problems according to the theme of the workshop. Students think of solutions to the problem and exchange ideas with one another. After that, students in the workshops discuss and synthesize their ideas for the problem. On the last day of the Festival, Students in the workshop present their problem-oriented solutions to all participants. After all, methods and products for the problem are exhibited (Table 5). The aim of the application stages determined for the Bademlik Design Festival was to be able to clearly observe the design movements of the student and the design products of each student.

Table 5. Defined application stages for the Bademlik Design Festival [developed by (Özdemir, 2018)]

\section{FINDINGS OF THE STUDY}

100 students and 16 instructors participated in the Bademlik Design Festival. A survey was conducted for the students and instructors participating in the festival. The survey consists of three parts: demographic structure, informal education experience and Bademlik Design Festival experience. According to the survey results, students from six different disciplines participated in the festival (Table 6). Most of the participants are the second grades students from different area of disciplines, which indicates that the organization has a multidisciplinary structure.

Table 6. Participants in the festival (Özdemir, 2018). 
The way an individual learns knowledge does not only depend on the mandatory curriculum. Activities such as workshops, competitions, seminars, festivals, summer schools and exhibitions held outside of school contribute to the acquisition of lifelong learning. In this sense, participants in Bademlik Design Festival think that informal structures contribute to their personal development and learning abilities (Table 7).

Table 7. Contribution of informal structures to education (Özdemir, 2018).

According to the results of the survey, $96 \%$ of students intend to participate in BTF. (Table 8a). Students participated in the festival by $61 \%$ friends, 31\% Social Media, 5\% posters and 3\% university teachers (Table 8b). 81\% of students think that the festival held in ESOGU does not restrict their freedom (Table 8c). 78\% of students found their festival quota adequate (Table 8d). Informal activities are not included in the graduation assessment in $86 \%$ of schools, although $68 \%$ of participants think they should be included in the graduation assessment (Table $8 \mathrm{e})$.

Table 8. Responses to the survey (Özdemir, 2018).

In result of the surveys, students participating in the Festival think that informal activities contribute to students' creativity, free and original design, professional assessment-rating, group work habits, and interdisciplinary cooperation. But students have not been able to reveal a clear discourse about whether informal activities create a competitive environment (Table 9).

Table 9. Contribution of informal activities to education (Özdemir, 2018).

\section{Evaluation of Survey and Observation Results}

As a result of the survey and observation of the instructors and students participating in the Bademlik Design Festival, the following results were reached:

- $\quad$ Students and instructors think that informal education conducted outside of school does not restrict the student's freedom of design and originality.

- $\quad$ BTF Design Club strives to provide the learning experience in out-of-school times by bringing the festival to a wide audience through social media.

- $\quad$ Participants from different countries, provinces, specializations and semesters interact in a critical and discussion environment.

Received 24 October 202D; Received in revised form I December 202D; Accepted 5 December 202D;

Available unline 17 December 2020

dai: 10.46291//CONTECHval4iss3ppll-29 
- $\quad$ During the Festival, students are exposed to both theoretical and experimental forms of learning.

- $\quad$ Students learn new information by participating in activities conducted during extracurricular times. They believe that such activities carried out during extra-school times can be taken as part of an internship or elective course in mandatory education.

- $\quad$ According to the data, students and instructors think that informal activities encourage students' creativity because they create free environments.

- $\quad$ The voluntary participation of students in the festival demonstrates their willingness to learn about the subjects they are interested in.

\section{CONCLUSIONS AND DISCUSSION}

The educational process has been shaped according to today's conditions and brings within new forms of learning. These forms of learning are formal and informal education. Formal education takes place depending on the specific curriculum, while informal education draws a more flexible way to gain new forms of learning.

Bademlik Design Festival, as an informal structure, brings together participants from different countries, provinces, specialties and semesters to approach the design problem from different directions. During the organization, a critical discussion environment is created. In this direction, participants gain the habit of socializing, learning new information, creativity, free and original design, and group work. It facilitates the acquisition of new acquisitions during out-of-school times.

In this article, BTF was examined within the scope of informal education. BTF helps to gain students' design ideas and practices under the concepts of interaction, free and original thought, innovation, communication/dialogue (Table 10).

Table 10. Contribution of informal structures to education (the graph was developed through Özdemir, 2018).

Workshops conducted within the scope of Bademlik Design Festival create mutual relations between student-student and instructor-student. Survey results show that students in workshops are constantly interacting. This interaction is an area where students are provided with psychological harmony in the group, perspectives of different cultures, experience of producing together, unity of different disciplines, active group work, fast and multifaceted work, and people from different disciplines can agree in the same logic. 
The Bademlik Design Festival takes place outside of school. Students are admitted to the workshops as volunteers. This contributes to the students' multifaceted thinking, assertiveness, self-confidence, self-discovery process, their inner orientation, self-expression, not hesitating to make mistakes, free and original thinking. There is also no vertical hierarchy between student and instructor.

Expert instructors conduct workshops at the Bademlik Design Festival. Instructors identify workshop topics that are open to today's conditions and innovations. Students participating in the workshop are open to innovations such as new knowledge, developing ideas, habits in different discussion environments, new technologies, experience, following the current process, gaining new social skills.

Another conceptual achievement brought by the Bademlik Design Festival is communicationdialogue. This concept allows students participating in the month to gain skills such as social environment, social communication, planning, contact with different minds and ways of thinking, and experience.

These concepts will pave the way for student-centered design actions that can be proposed for architectural education in the future. It is believed that such studies, which take the student to the center, will occupy an important place in the field of architectural education. In this sense, it is thought that this article will provide opportunities for them to develop a new approach to the work in the field of architectural education. Based on these determined definitions, informal education should be supported and made widespread.

\section{ACKNOWLEDGEMENT}

This study is derived from the master's thesis titled "Mimarlık Eğitiminde Enformel Yapılar: ESOGÜ Bademlik Tasarım Festivali Örneği” prepared by Hüseyin Özdemir at Graduate Educatıon Institute of Eskısehir Osmangazi University. (Advisor: Prof. Dr. Ayşen Çelen Öztürk and Assoc. Prof. Dr. Gökçe Ketizmen Önal)

\section{REFERENCES}

Adıgüzel, D. (2012). Mimarlığın Enformel Eğitim Alanı Olarak Çevresel Yaklaşım Konulu Yarışmalar: Ekopavyon Proje Yarışması Örneği.

Beycan, A. D. O., Kuyrukçu, E. Y., \& Kuyrukçu, Z. (2014). Informal Activities in Architecture Training: A Summer School Sample Historical Elmalı Town. Procedia - Social and Behavioral Sciences(143), 92 - 98.

Ciravoğlu, A. (2001). Mimari Tasarım Ĕgitiminde Workshop-Stüdyo Paralelliği Üzerine. (Yüksek Lisans Tezi), İstanbul Teknik Üniversitesi, 
Ciravoğlu, A. (2003). Mimari Tasarım Eğitiminde Formel ve Enformel Çalışmalar Üzerine.

Coombs, P. H., \& Ahmed, M. (1974). Attacking Rural Poverty How Nonformal Education Can Help. Baltimore and London: The Johns Hopkins University Press.

Dib, C. Z. (1988). Formal, Non-Formal and Informal Education: Concepts/Applicability. Paper presented at the Cooperative Networks in Physics Education, New York.

Erktin, E., \& Soygeniş, S. (2014). Learning by Experiencing the Space : Informal Learning Environments in Architecture Education. Boğaziçi University Journal of Education, 31(1), 8192.

Goodyear, P. (2000). Environments for Lifelong Learning: Ergonomics, architecture and educational design. In S. J.M. \& A. T.M. (Eds.), Integrated and Holistic Perspectives on Learning, Instruction and Technology.

Hassanpour, B., Che-Ani, A. I., Usman, I. M. S., Johar, S., \& Tawil, N. M. (2015). Lifelong Learning in Architectural Design Studio: The Learning Contract Approach International Education Studies, 8(1).

İnce, M., \& Yarkataş, Ö. I. (2017). Design Workshops and Their Importance. Anadolu Üniversitesi Sanat \& Tasarım Dergisi, 7(2).

Kahvecioğlu, N. P. (2007). Architectural design studio organization and creativity. ITU A|Z, 4(2), 6-26.

Koper, R., \& Tattersall, C. (2004). New directions for lifelong learning using network technologies. British Journal of Educational Technology, 35(6), 689-700.

Ledewitz, S. (1985). Models of Design in Studio Teaching. Journal of Architectural Education, 38(2), 2-8.

Levy, A. (1980). Total Studio. Technics and Design Education, 34(2), 29-32.

Önal, G. K. (2017). Searching Creativity: (N)On Place Design Workshop. Design and Technology Education: An International Journal, 2(22), 58-82.

Özdemir, H. (2018). Mimarlı Eğitiminde Enformel Yapılar: ESOGÜ Bademlik Tasarım Festivali Örneği. (Yüksek Lisans Tezi),

Öztürk, A. Ç. (2019). Mimarlık Okullarında Tasarım Stüdyoları: Farklı Denemeler: YEM Yayin.

Polatoglu, C., \& Vural, S. M. (2012). As an educational tool the importance of informal studies/studios in architectural design education; case of Walking Istanbul 1\&2. Procedia Social and Behavioral Sciences(47), 480-484.

Schön, D. A. (1983). The Reflective Practitioner: How Professionals Think in Action: A Member of the Perseus Books Group.

Received 24 Octaber 2020; Received in revised form I December 2020; Accepted 5 December 2020;

Available online 17 December 2020

dai: 10.4629I//CONTECHval4iss3̈ppll-29 
Schön, D. A. (1985). The Design Studio, An Exploration of its Traditions and Potentials. London,England: RIBA Publications Limited Finsbury Mission.

Turgut, H., \& Cantürk, E. (2015). Design workshops as a tool for informal architectural education. Open House International, 40(2), 88-95.

Türkmen, Ç. (2020). Outer Studio: Learning from the Students. Thresholds in Architectural Education, 209-220. doi:10.1002/9781119751427.ch16

Vadeboncoeur, J. A. (2006). Engaging Young People: Learning in Informal Contexts. American Educational Research Association, 30, 239-278.

Yürekli, İ. (2003). Mimari Tasarım Eğitiminde Oyun. (Doktora Tezi), İstanbul Teknik Üniversitesi,

Yürekli, İ., \& Yürekli, H. (2004). Mimari Tasarım Eğitiminde Enformellik. itüdergisi/a, 3(1), 53-62. 
Table 1. Interaction of formal, informal and forms of learning from literature (the graph was developed by Özdemir, 2018).
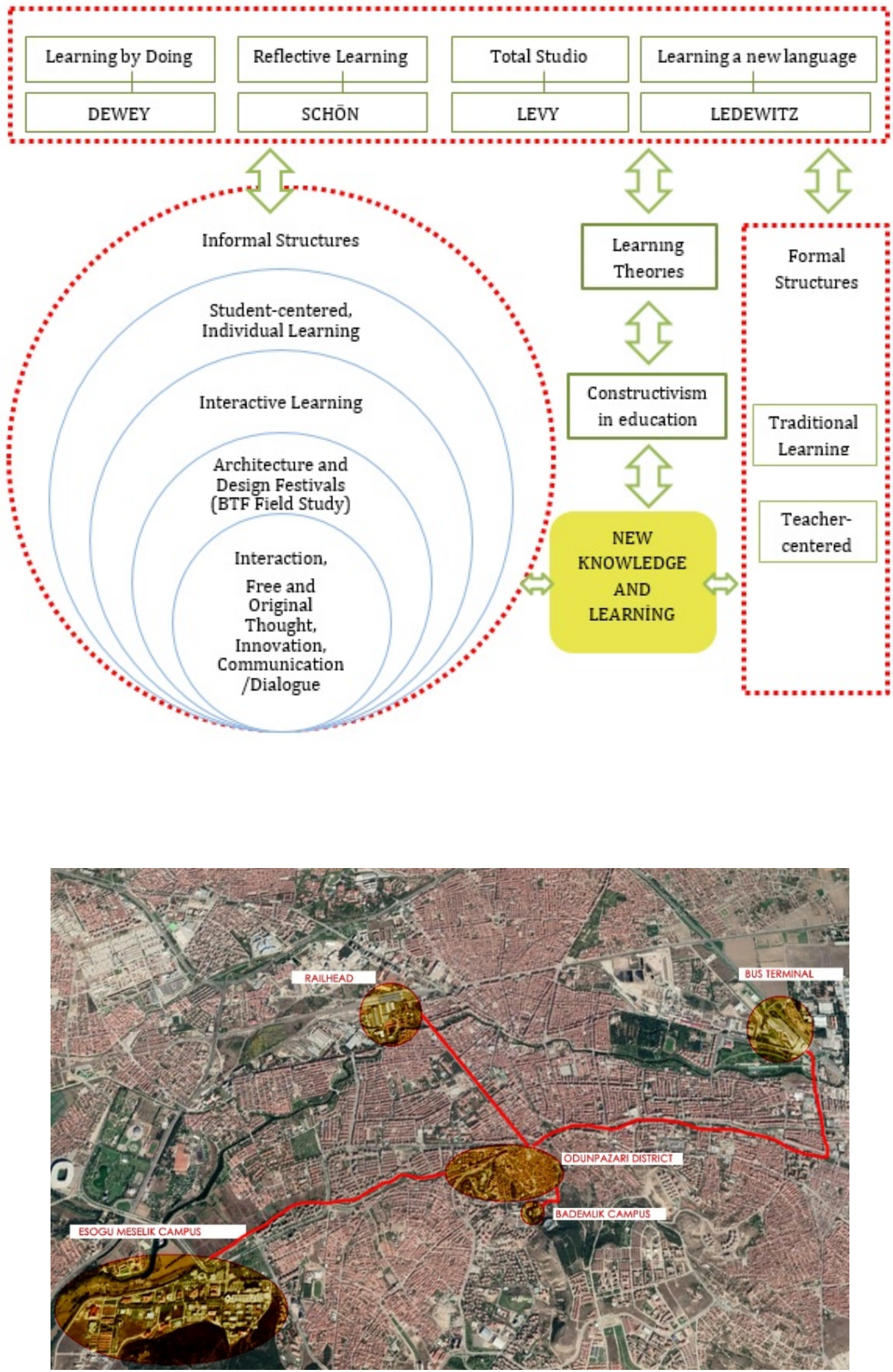

Figure 1. Eskisehir Osmangazi University Department of Architecture Bademlik Campus

Received 24 Dctaber 2020; Received in revised farm I December 202D; Accepted 5 December 202D;

Available unline 17 December 2020

dai: 10.46291//CONTECHvol4iss3ppll-29 
Table 2. Bademlik Design Festival themes and workshops from 2013 to 2017 (Özdemir, 2018)

\begin{tabular}{|c|c|c|}
\hline & $\begin{array}{l}\text { Bademlik } \\
\text { Design Festival } \\
\text { Themes }\end{array}$ & $\begin{array}{l}\text { Workshops Organized Under Bademlik } \\
\text { Design Festival }\end{array}$ \\
\hline BTF 2013 & $\begin{array}{l}\text { Think-Design- } \\
\text { Work }\end{array}$ & $\begin{array}{l}\text { Cartoon workshop, Heroes on canvas } \\
\text { workshop, (N) On Place workshop, Cut-at } \\
\text { Workshop, Experimental Form workshop, } \\
\text { Urban puzzle workshop, Character Design } \\
\text { Workshop, Short Film Workshop and Arch } \\
\text { Games Workshop }\end{array}$ \\
\hline BTF 2014 & Invasion & $\begin{array}{l}\text { Improvisation Workshop, White Balloon } \\
\text { Workshop, Existence In The Body Workshop, } \\
\text { Music Games With The Body Workshop, Move } \\
\text { Workshop, Invader Eye Workshop, Form } \\
\text { Invasion Workshop, Art + Ik + Art Workshop, } \\
\text { Ancient Moche Masks Workshop, After Them } \\
\text { On The Water Workshop }\end{array}$ \\
\hline BTF 2015 & Stain & $\begin{array}{l}\text { Spotless, Bla Bla, Stain, Spontaneity, I Wore } \\
\text { Eskisehir, Positive Stain, Present Times, } \\
\text { Formless, Primitive-Trace, Invertthelight }\end{array}$ \\
\hline BTF 216 & $\begin{array}{l}\text { What Does } \\
\text { Design Do When } \\
\text { Layout } \\
\text { Disintegrates? }\end{array}$ & $\begin{array}{l}\text { Intersection, 122/1, Giga Mapping, Humanji, } \\
\text { Temporary immigrant, Street art, Wearable } \\
\text { Lives, No End, } 2 \text { Dec } 1 \text { I, KoruGAN, Painting } \\
\text { Workshop, FormDD, Tiles in Motion, } \\
\text { Confrontation }\end{array}$ \\
\hline 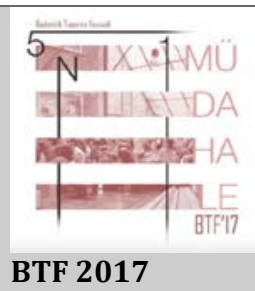 & $\begin{array}{l}5 \mathrm{~N} 1 \\
\text { Intervention }\end{array}$ & $\begin{array}{l}\text { Replicating bonds, intervention in nature, } \\
\text { unregistered Eskisehir Atlas, intervention } \\
\text { against urban intervention, Khora II: Why not?, } \\
\text { Space text relationship, ditch and Shadow, } \\
\text { possible, so-called Hidden Spaces, Destruction }\end{array}$ \\
\hline
\end{tabular}


Table 3. Method of Research

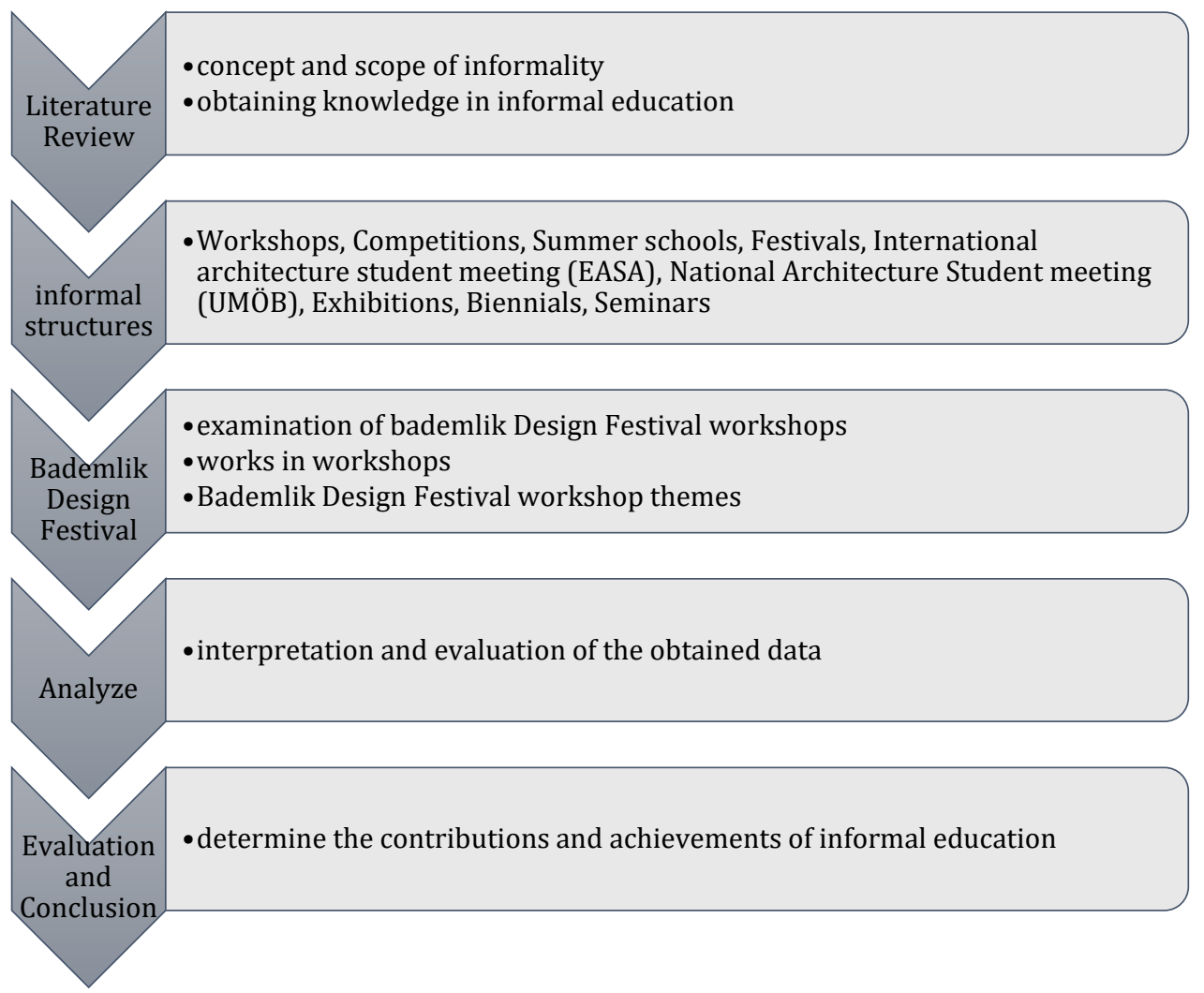

Table 4. Bademlik Design Festival Workshops held in 2018
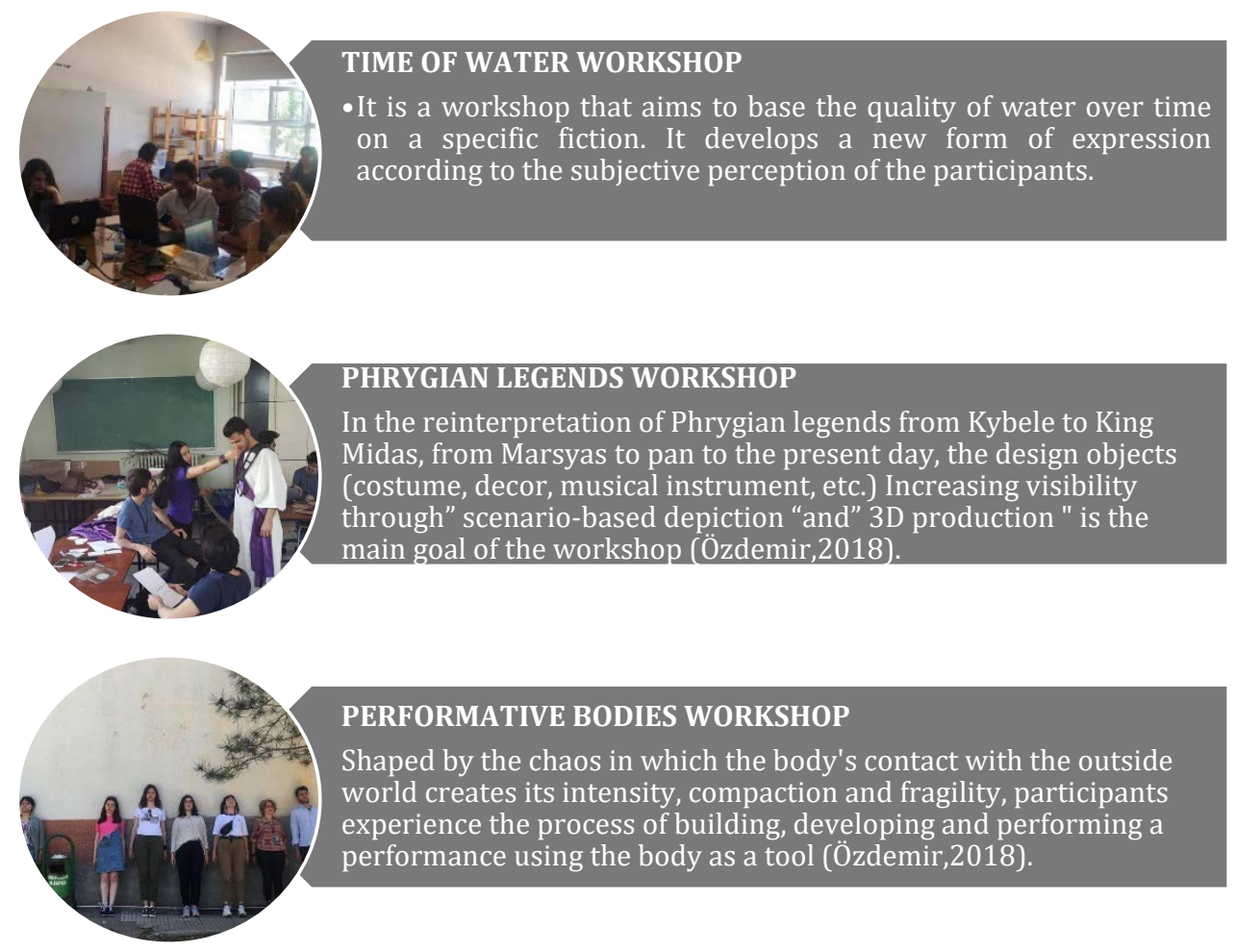

PERFORMATIVE BODIES WORKSHOP

Shaped by the chaos in which the body's contact with the outside world creates its intensity, compaction and fragility, participants experience the process of building, developing and performing a performance using the body as a tool (Özdemir,2018).

Received 24 Dctaber 2020; Received in revised farm I December 202D; Accepted 5 December 202D;

Available unline 17 December 2020

dai: 10.46291//CONTECHvol4iss3ppll-29 
ICONTECH INTERNATIONAL JOURNAL OF SURVEYS, ENGINEERING, TECHNOLOGY

ISSN 2717-7270

Journal homepage: http://icontechjournal.com/index.php/iij
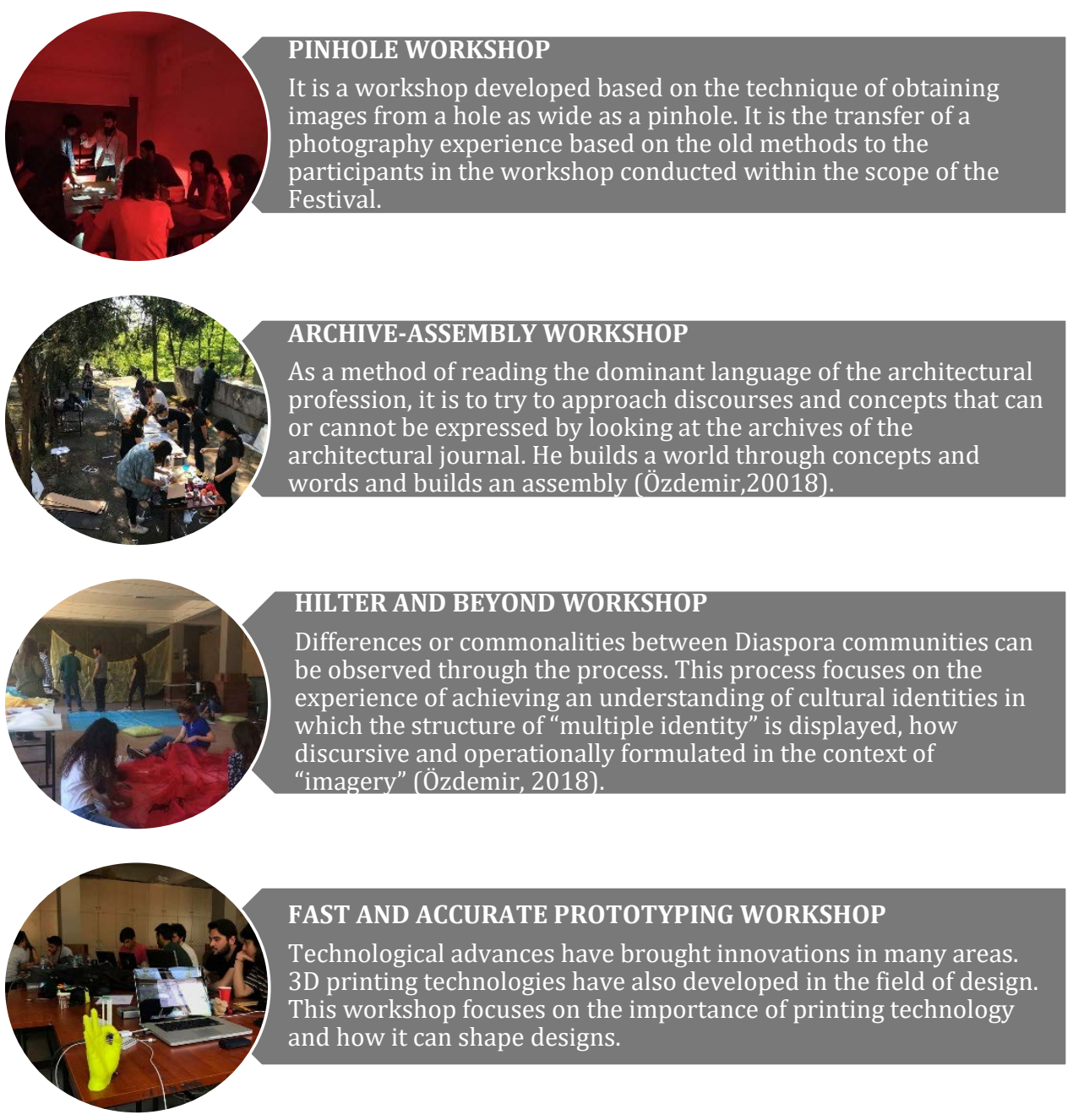

FAST AND ACCURATE PROTOTYPING WORKSHOP

Technological advances have brought innovations in many areas. 3D printing technologies have also developed in the field of design. This workshop focuses on the importance of printing technology and how it can shape designs.

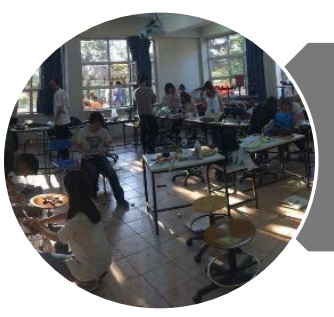

ONBETAALBAAR WORKSHOP

Onbetaalbaar workshop is the experience of designers to reveal these meanings through materials based on the philosophy of emotion, ecological and economic meaning that the object loads (Özdemir,2018).

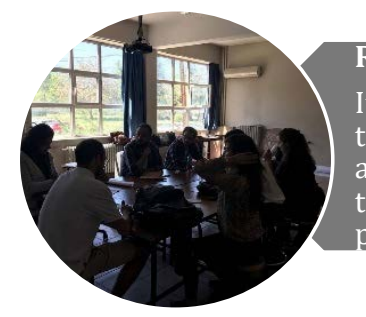

REMEMBER-FORGET-SAVE-RE-ESTABLISH WORKSHOP

It is a workshop that deals with looking at the relationship between time and memory by putting our own past and present. It provides an experience in fiction that the participant records and presents their individual story to the extent that they remember it with photos and objects that they carry to the workshop (özdemir,2018).

Received 24 Dctaber 2020; Received in revised farm I December 202D; Accepted 5 December 202D; Available unline 17 December 2020 dai: 10.46291//CONTECHvol4iss3pppll-29 

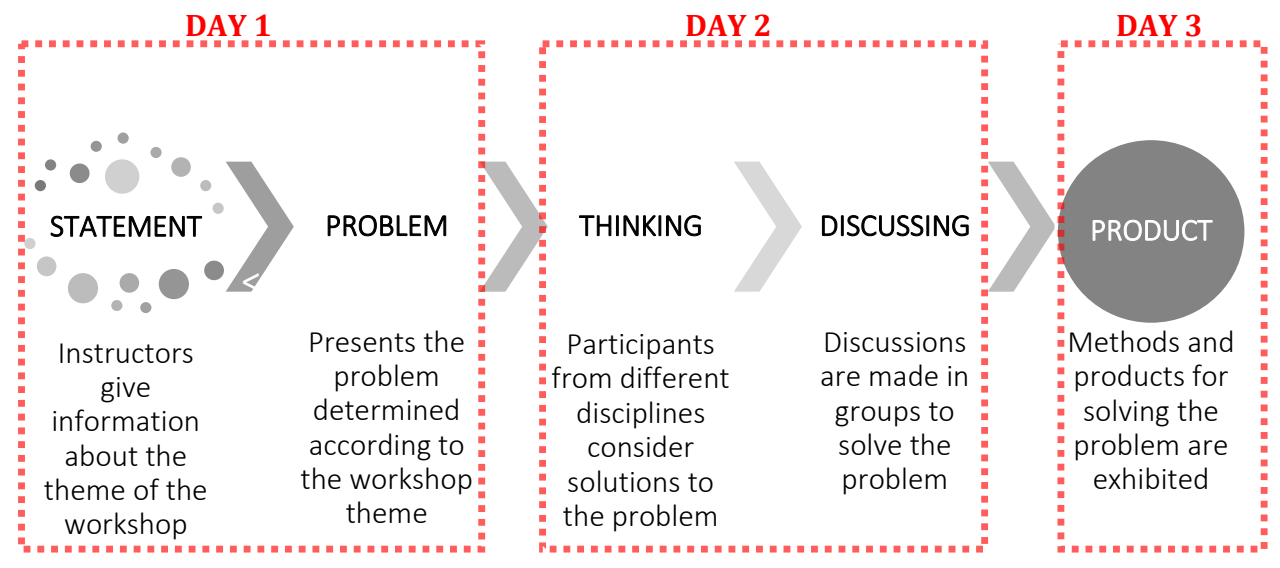

Table 6. Participants in the festival (Özdemir, 2018).

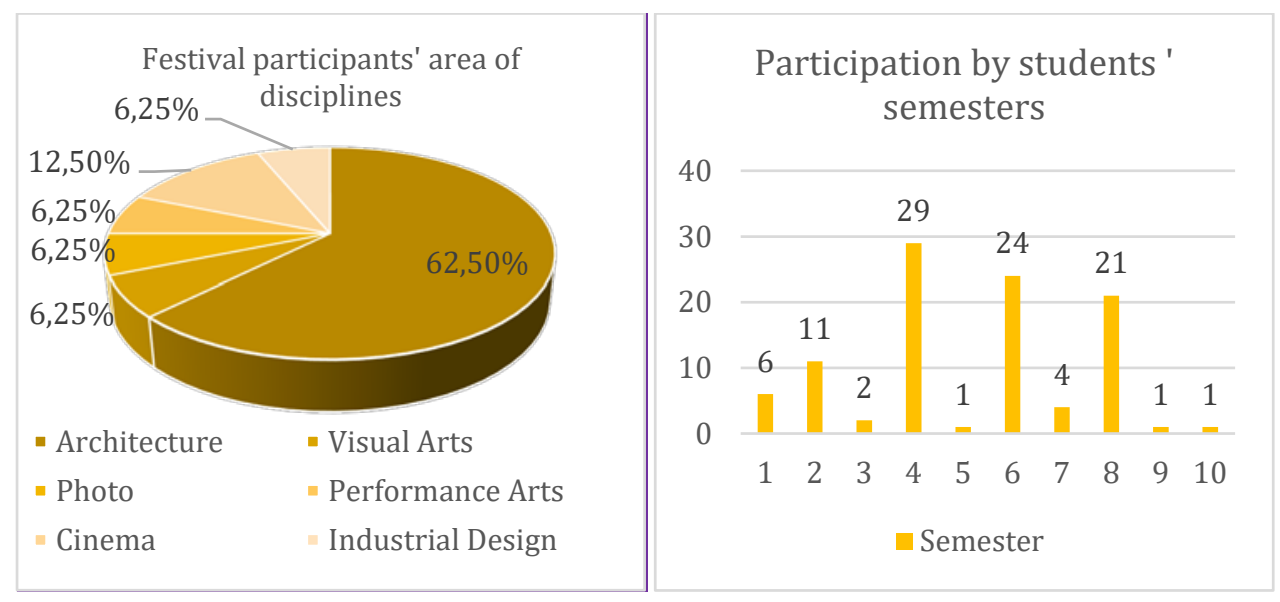

Table 7. Contribution of informal structures to education (Özdemir, 2018).

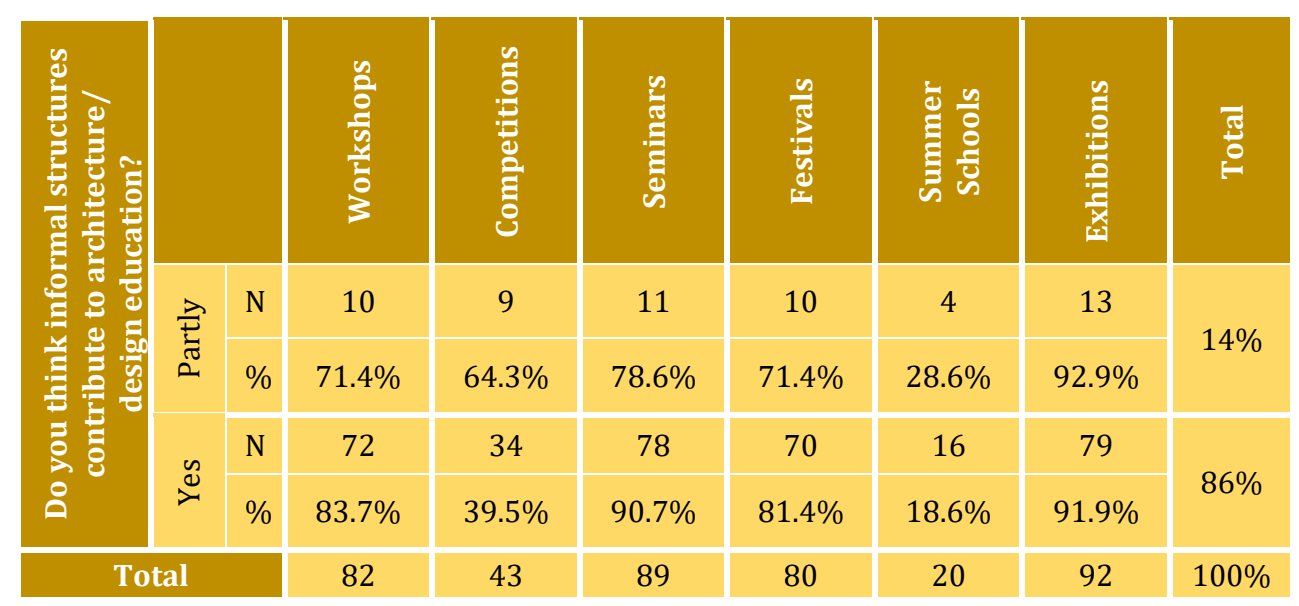

Received 24 Dctober 2020; Received in revised farm I December 2020; Accepted 5 December 2020;

Available online 17 December 2020

doi: I0.46291/ICONTECHvol4iss3ppll-29 
Table 8. Responses to the survey (Özdemir, 2018).

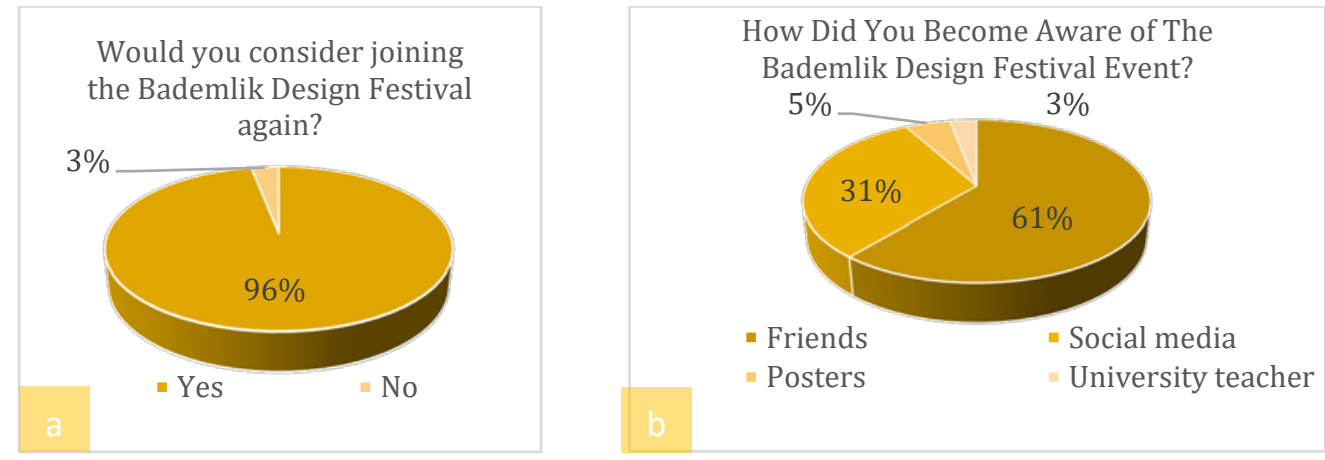

Does having an informal structure in the content of Esogu Architecture Department (such as BTF), which is a formal structure of the event, restrict the freedom of the festival?

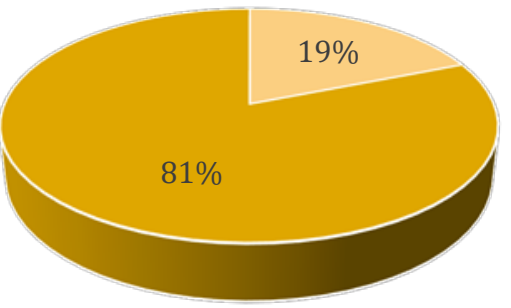
$\because$ Yes No

state your opinion on" participant quotas".

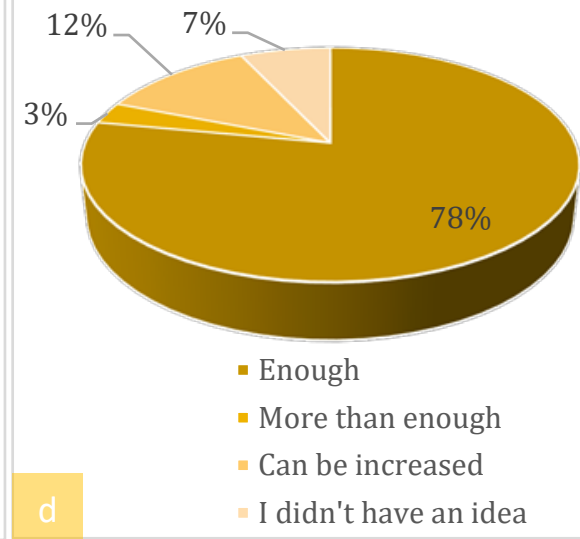

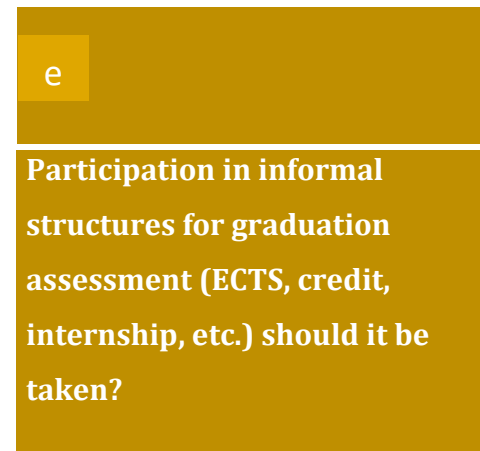

In your school, participation in informal structures, graduation assessment (ECTS, credit, internship, etc.) getting?

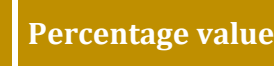

Graduation assessment the format of the receipt

\section{No}

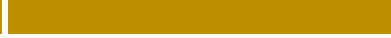

(

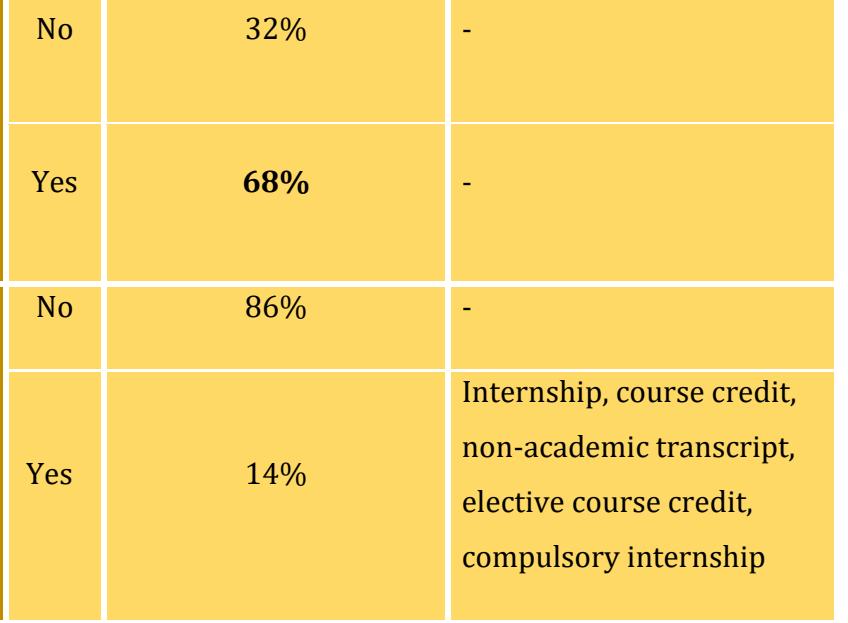

Table 9. Contribution of informal activities to education (Özdemir, 2018).

Received 24 Dctaber 2020; Received in revised farm I December 202D; Accepted 5 December 202D;

Available unline 17 December 2020

dai: 10.46291//CONTECHvol4iss3ppll-29 
ICONTECH INTERNATIONAL JOURNAL OF SURVEYS, ENGINEERING, TECHNOLOGY

ISSN 2717-7270

Journal homepage: http://icontechjournal.com/index.php/iij

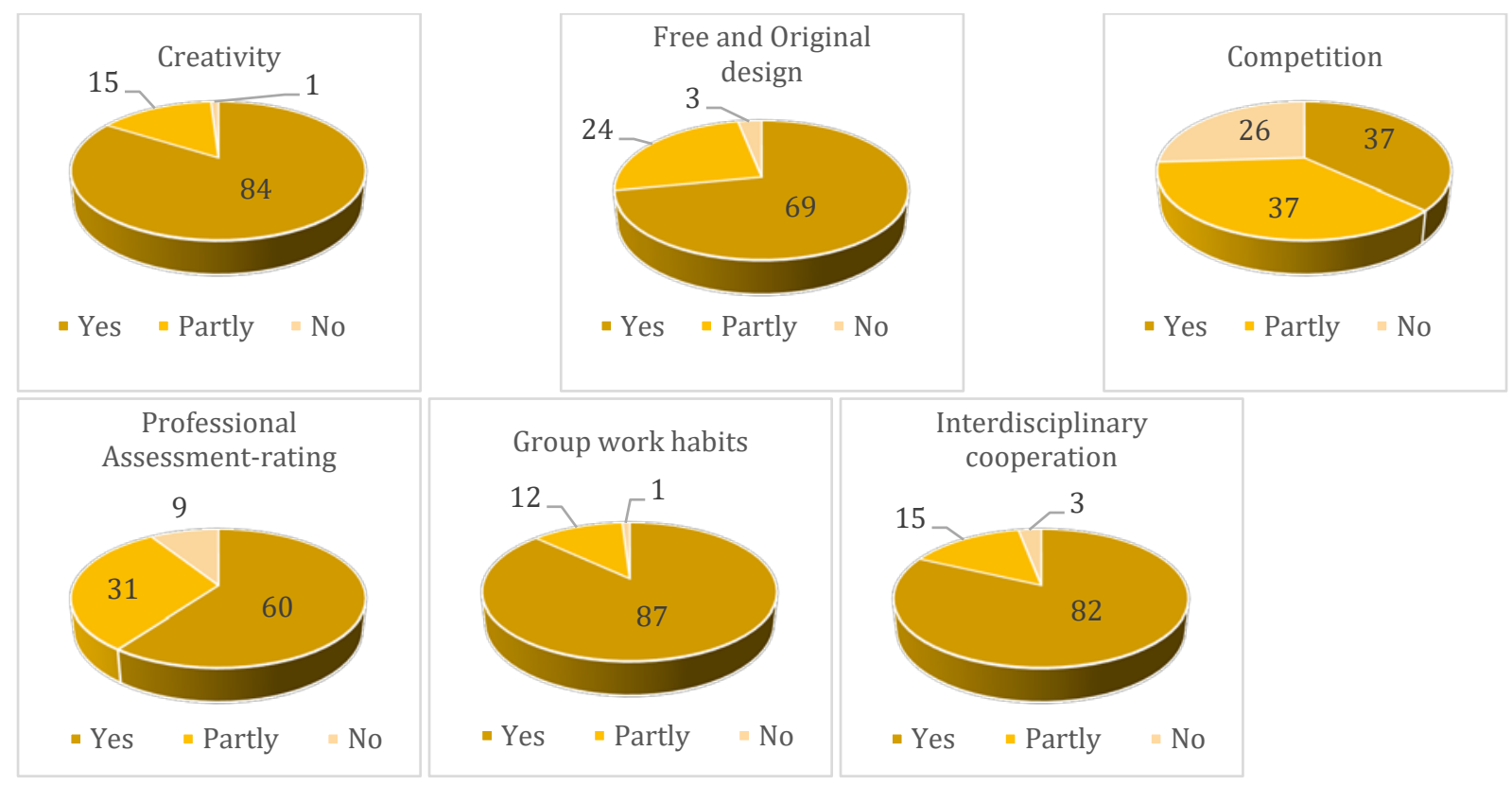

Received 24 Dctober 2020; Received in revised form I December 2020; Accepted 5 December 2020;

Available unline 17 December 2020

doi: I0.46291//CDNTECHvol4iss3ppll-29 
Table 10. Contribution of informal structures to education (the graph was developed through Özdemir, 2018).

\begin{tabular}{|c|c|c|}
\hline $\begin{array}{l}\text { *In-Group psychological } \\
\text { adaptation } \\
\text { *Multidisciplinary } \\
\text { thinking } \\
\text { *Experience producing } \\
\text { together } \\
\text { *Perspectives of different } \\
\text { cultures }\end{array}$ & BTF ACHIEVEMENTS & $\begin{array}{l}\text { *Different discipline unity } \\
\text { *Active group work } \\
\text { *Fast and versatile work } \\
\text { *People from very } \\
\text { different disciplines from } \\
\text { education can agree on } \\
\text { the same logic }\end{array}$ \\
\hline $\begin{array}{l}\text { *Multifaceted thinking } \\
\text { *Enterprise } \\
\text { *Self-confidence } \\
\text { *The process of } \\
\text { discovering myself and } \\
\text { my environment }\end{array}$ & $\begin{array}{l}\text { FREE AND } \\
\text { ORIGINAL } \\
\text { THINKING }\end{array}$ & $\begin{array}{l}\text { *Internal orientations } \\
\text { *To express yourself } \\
\text { *Destroying the vertical } \\
\text { hierarchy } \\
\text { *Not afraid to make } \\
\text { mistakes }\end{array}$ \\
\hline $\begin{array}{l}\text { *New information } \\
\text { *Idea developer } \\
\text { *Habitual to different } \\
\text { discussion environments }\end{array}$ & ATION & $\begin{array}{l}* \text { New technologies } \\
* \text { Experience } \\
\text { *Following the process } \\
\text { *Cnrinl slills }\end{array}$ \\
\hline $\begin{array}{l}\text { *Social environment } \\
\text { *Increases social } \\
\text { communication } \\
\text { *Experience }\end{array}$ & $\begin{array}{l}\text { COMMUNICATION } \\
\text { AND DIALOGUE }\end{array}$ & $\begin{array}{l}\text { *The process of } \\
\text { specialization } \\
\text { *Planning } \\
\text { *Touching different minds } \\
\text { and ways of thinking }\end{array}$ \\
\hline
\end{tabular}

